\title{
Preoperative and postoperative risk factors in laparoscopic cholecystectomy converted to open surgery
}

\author{
Uğur Ekici ${ }^{1, A, B, D}$, Faik Tatt|2,B,C, Murat Kanlı̈̈z ${ }^{3, B, C, E, F}$ \\ ${ }^{1}$ General Surgery Department, Esencan Hospital, Istanbul, Turkey \\ 2 General Surgery Department, Harran University, Urfa, Turkey \\ ${ }^{3}$ General Surgery Department, Atatürk Research and Education Hospital, Ankara, Turkey \\ A - research concept and design; B - collection and/or assembly of data; $C$ - data analysis and interpretation; \\ $\mathrm{D}$ - writing the article; $\mathrm{E}$ - critical revision of the article; $\mathrm{F}$ - final approval of the article
}

\section{Address for correspondence \\ Uğur Ekici \\ E-mail: opdrugurekici@hotmail.com}

Funding sources

None declared

Conflict of interest

None declared

Received on April 8, 2016

Reviewed on June 20, 2016

Accepted on December 21, 2017

Published online on April 13, 2019

Cite as

Ekici U, Tatlı F, Kanliöz M. Preoperative and postoperative risk factors in laparoscopic cholecystectomy converted to open surgery. Adv Clin Exp Med. 2019;28(7):857-860. doi:10.17219/acem/81519

DOI

10.17219/acem/81519

\section{Copyright}

Copyright by Author(s)

This is an article distributed under the terms of the

Creative Commons Attribution Non-Commercial License

(http://creativecommons.org/licenses/by-nc-nd/4.0/)

\begin{abstract}
Background. Laparoscopic cholecystectomy (LC) is nowadays the gold standard in the surgical treatment of cholelithiasis and gallbladder diseases. But sometimes it may be inevitable to convert it to open surgery to safely end the procedure.

Objectives. In this study, we aimed to investigate the risk factors for conversion to open surgery from LC.

Material and methods. The records of patients that underwent LC in Malatya State Hospital (Malatya, Turkey) between January 2013 and May 2014 were prospectively examined. One hundred and forty-five patients were involved in this study. The patients were divided into 2 groups: LC patients and patients converted to open surgery. For the patients in both groups, the preoperative age, gender, body mass index (BMI), disease history, previous abdominal operations, and preoperative laboratory findings were recorded, as well as the fact if the abdominal ultrasonography (US) and endoscopic retrograde cholangiopancreatography (ERCP) were performed.
\end{abstract}

Results. Of 145 patients involved in this study, 127 (87.5\%) were female and 18 (12.5\%) were male; their mean age was 46.54 years. Nineteen of the patients were operated on after ERCP due to acute cholecystitis and 6 patients were operated on after ERCP due to choledocholithiasis. In 134 of the patients (92.4\%), the operations were completed laparoscopically, while the process was converted to open surgery in 11 cases (7.6\%). Male gender, chronic disease history, normal BMl level, increased thickness of the gallbladder wall, increased preoperative blood glucose level, leukocytosis, preoperative ERCP history, grade 3 or 4 (Blauer scoring system) adhesions determined during the operation, and multiple stone presence in the bladder were found to be statistically significant risk factors for conversion to open surgery.

Conclusions. Patients in the risk group should be informed by experienced laparoscopic surgeons about the potential conversion to open surgery and decision on such conversion should be made when necessary.

Key words: cholelithiasis, laparoscopic cholecystectomy, conversion 


\section{Introduction}

Laparoscopic cholecystectomy (LC) is superior to open cholecystectomy because of less postoperative pain, shorter hospitalization duration, shorter time for returning to daily activities, less surgical scarring, and better cosmetic results. ${ }^{1}$ The reason for conversion to open surgery during $\mathrm{LC}$ is to prevent severe complications that may occur during the operation. ${ }^{2}$ Conversion to open surgery should not be considered a complication, but as a procedure necessary to complete the operation safely. Knowing the risk factors for conversion to open surgery is important for informing the patient about this topic.

The aim of this study is to determine the risk factors leading to conversion from LC to open surgery.

\section{Material and methods}

One hundred and forty-five patients who underwent LC surgery in Malatya State Hospital (Malatya, Turkey) between January 2013 and May 2014 were involved in this study and their data was retrospectively examined. One hundred and forty-one patients were operated on due to choledocholithiasis, while 4 patients were operated on due to gallbladder polyp. The operations were performed by 3 exprienced surgeons in the American position with the classic 4 trocars method. Dissection was performed with a dissector in Calot's triangle. The patients were divided into 2 groups: LC patients and patients converted to open surgery. For the patients in both groups, the preoperative age, gender, body mass index (BMI), disease history, previous abdominal operations, and preoperative laboratory findings were recorded, as well as the fact if the abdominal ultrasonography (US) and endoscopic retrograde cholangiopancreatography (ERCP) were performed. The findings during the operation were also recorded. A $>3 \mathrm{~mm}$ increase in the gallbladder wall in ultrasonography was considered increased wall thickness (acute cholecystitis). Fasting blood glucose (FBG), number of white blood cells (WBC), alanine aminotransferase (ALT), aspartate aminotransferase (AST), gamma-glutamyl transferase (GGT), and alkaline phosphatase (ALP) values were examined and recorded. White blood cells $>10,000 / \mathrm{mm}^{3}$, AST $>35 \mathrm{IU} / \mathrm{L}$, ALT > $55 \mathrm{IU} / \mathrm{L}, \mathrm{GGT}>65 \mathrm{IU} / \mathrm{L}, \mathrm{ALP}>150 \mathrm{IU} / \mathrm{L}$, and FBG > $105 \mathrm{mg} / \mathrm{dL}$ values were considered increased.

In all of the patients, the level of abdominal adhesion was evaluated in accordance with the Blauer scoring system (grade 0 - no adhesion; grade 1 - thin and narrow, and easy-to-separate adhesions; grade 2 - thick adhesions limited to a certain region; grade 3 - thick and widespread adhesion; grade 4 - thick and widespread adhesion, adhesion of viscera to the front and back abdominal wall). ${ }^{3}$ Body mass index $<20$ was considered thin, 20-25 was considered normal, 25-30 - overweight, 30-35 - obese, and >35 - morbidly obese.
For statistical analyses, SPSS v. 18.0 software (SPSS Inc., Chicago, USA) was used. Evaluation of risk factors was performed using Pearson's $\chi^{2}$ test. P-value $<0.05$ was considered statistically significant.

\section{Results}

Of the 145 patients involved in this study, 127 (87.5\%) were male and $18(22.5 \%)$ were female. Their mean age was 46.54 years (17-84). While the operation was accomplished laparoscopically in $134(92.4 \%)$ patients, it was converted to open surgery in 11 (7.6\%) cases. The reasons for conversion to open surgery are presented in Table 1 . No complications were observed during or after the surgery.

It was observed that the conversion to open surgery was statistically significantly more frequent in male patients than in female patients $(\mathrm{p}<0.01)$. Mean BMI of the patients was calculated to be 28.9. The risk of conversion to open surgery was statistically significantly higher in patients in the normal BMI category $(\mathrm{p}=0.01)$ (Table 2). It was found to be statistically significantly higher in patients having chronic disease or increased gallbladder wall thickness in ultrasonography, and in those who underwent ERCP before the operation. The adhesion of the gallbladder to adjacent organs during the operation was found

Table 1. Reasons for conversion from laparoscopic cholecystectomy (LC) to open surgery

\begin{tabular}{|l|c|}
\multicolumn{1}{|c|}{ Reason } & Number of patients \\
\hline Adhesion & $6(54.5 \%)$ \\
\hline Hemorrhage & $2(18.2 \%)$ \\
\hline Cancer & $1(9.1 \%)$ \\
Mirizzi syndrome & $2(18.2 \%)$ \\
\hline Total & 11 \\
\hline
\end{tabular}

Table 2. Demographic factors

\begin{tabular}{|c|c|c|c|}
\hline Parameter & $\begin{array}{l}\text { LC group } \\
(\mathrm{n}=134 \\
(92.4 \%))\end{array}$ & $\begin{array}{l}\text { Open surgery } \\
\text { group } \\
(n=11(7.6 \%))\end{array}$ & $p$-value \\
\hline $\begin{array}{l}\text { Advanced age } \\
\text { >mean age ( } 46.54 \text { years) } \\
<\text { mean age ( } 46.54 \text { years) }\end{array}$ & $\begin{array}{l}61(45.5 \%) \\
73(54.5 \%)\end{array}$ & $\begin{array}{l}8(73.0 \%) \\
3(27.0 \%)\end{array}$ & 0.82 \\
\hline $\begin{array}{l}>65 \text { years } \\
<65 \text { years }\end{array}$ & $\begin{array}{c}15(11.2 \%) \\
119(88.8 \%)\end{array}$ & $\begin{array}{c}1(9.1 \%) \\
10(90.9 \%)\end{array}$ & 0.83 \\
\hline $\begin{array}{l}\text { Gender } \\
\text { female } \\
\text { male }\end{array}$ & $\begin{array}{c}21(90.3 \%) \\
13(9.7 \%)\end{array}$ & $\begin{array}{l}6(54.5 \%) \\
5(45.5 \%)\end{array}$ & 0.005 \\
\hline $\begin{array}{l}\text { BMI } \\
\text { >mean BMI (28.91) } \\
\text { <mean BMI (28.91) }\end{array}$ & $\begin{array}{l}64(47.7 \%) \\
70(53.3 \%)\end{array}$ & $\begin{array}{l}3(27.7 \%) \\
8(73.7 \%)\end{array}$ & 0.19 \\
\hline BMI 20-25 & 16 (11.9\%) & $5(45.5 \%)$ & \multirow{3}{*}{0.01} \\
\hline BMI 25-30 & 55 (41\%) & $4(36.3 \%)$ & \\
\hline $\mathrm{BMI}>30$ & $51(38 \%)$ & $2(18.2 \%)$ & \\
\hline
\end{tabular}

LC - laparoscopic cholecystectomy; BMI - body mass index. 
Table 3. History, physical examinations and intra-operative findings

\begin{tabular}{|l|c|c|c|}
\hline \multicolumn{1}{|c|}{ Parameter } & $\begin{array}{c}\text { LC group } \\
(\mathrm{n}=134 \\
(92.4 \%))\end{array}$ & $\begin{array}{c}\text { Open surgery } \\
\text { group } \\
(\mathrm{n}=11(7.6 \%))\end{array}$ & p-value \\
\hline Chronic disease & $\begin{array}{c}40(29.9 \%) \\
7(63.6 \%)\end{array}$ & 0.02 \\
\hline Previous abdominal surgery & $30(22.3 \%)$ & $1(9 \%)$ & 0.3 \\
\hline ERCP history & $5(3.7 \%)$ & $1(9 \%)$ & 0.03 \\
\hline Former cholecystitis attack & $53(39.5 \%)$ & $7(63.6 \%)$ & 0.11 \\
\hline $\begin{array}{l}\text { Increased wall thickness } \\
\text { in USG }\end{array}$ & $13(9.7 \%)$ & $6(54.5 \%)$ & 0.002 \\
\hline $\begin{array}{l}\text { Multiple stone presence } \\
\text { Pre-operative adhesion } \\
\text { grade 0 } \\
\text { grade 1-2 } \\
\text { grade 3-4 }\end{array}$ & $\begin{array}{c}8(65.6 \%) \\
10(40.8 \%)\end{array}$ & $\begin{array}{c}0(0 \%) \\
0(0 \%)\end{array}$ & 0.003 \\
\hline
\end{tabular}

LC - laparoscopic cholecystectomy; ERCP - endoscopic retrograde cholangiopancreatography.

Table 4. Laboratory values

\begin{tabular}{|l|c|c|c|}
\multicolumn{1}{|c|}{ Parameter } & $\begin{array}{c}\text { LC group } \\
(n=134 \\
(92.4 \%)\end{array}$ & $\begin{array}{c}\text { Open surgery } \\
\text { group } \\
(n=11(7.6 \%))\end{array}$ & p-value \\
\hline $\mathrm{WBC}>10,000 / \mathrm{mm}^{3}$ & $17(12.6 \%)$ & $4(36.6 \%)$ & 0.03 \\
\hline AST > 35 IU/L & $14(10.4 \%)$ & $1(9 \%)$ & 0.88 \\
\hline ALT > 55 IU/L & $14(10.4 \%)$ & $0(0 \%)$ & 0.25 \\
\hline GGT > 65 IU/L & $18(13.4 \%)$ & $1(9 \%)$ & 0.68 \\
\hline ALP > 150 IU/L & $7(5.2 \%)$ & $0(0 \%)$ & 0.43 \\
\hline Glucose $>105 \mathrm{mg} / \mathrm{dL}$ & $40(29.8 \%)$ & $7(63.3 \%)$ & 0.02 \\
\hline
\end{tabular}

LC - laparoscopic cholecystectomy; WBC - number of white blood cells; AST - aspartate aminotransferase; ALT - alanine aminotransferase; GGT - gamma-glutamyl transferase; ALP - alkaline phosphatase.

to be a risk factor for conversion to open surgery. According to the Blauer adhesion classification, there were grade 3 or 4 adhesions in all of the patients (11 cases) in case of whom operations were converted to open surgery ( $\mathrm{p}<0.01)$. In 75 patients having grade 1 and 2 adhesion and 59 patients having no adhesion (grade 0 ), the operation was accomplished laparoscopically. Among the reasons that may lead to adhesion, abdominal operation history was present in 31 patients. Conversion to open surgery was performed in only 1 of those patients (Table 3 ).

It was observed that the risk of conversion to open surgery was statistically significantly higher in patients having a preoperative blood glucose level higher than $105 \mathrm{mg} / \mathrm{dL}$ $(\mathrm{p}=0.02)$. Of 17 patients having preoperative leukocytosis, 4 were converted to open surgery and that was statistically significant $(\mathrm{p}<0.03)$ (Table 4$)$.

\section{Discussion}

Laparoscopic cholecystectomy is presently the gold standard in surgical treatment of cholelithiasis and gallbladder diseases. But sometimes it may be inevitable to convert it to open surgery to safely end the procedure. Since the first LC in 1987, because of advancements in surgical experience and devices, the rate of conversion to open surgery has decreased gradually. In current publications, this rate is reported to be between $6.3 \%$ and $11.5 \%{ }^{4,5}$ It was found to be $7.6 \%$ in our study.

Conversion to open surgery in LC is not a complication, but it may be a necessity to safely end the procedure. The real complications in LC are hemorrhage, perforation of the gallbladder, biliary leakage, biliary tract injury, and organ injury. ${ }^{6}$ Conversion to open surgery may prevent these potential complications. In order to inform the patient before the operation and to continue the treatment process, it is important to determine the risk factors requiring the conversion to open surgery.

In much of the literature, it has been reported that advanced age, male gender, acute cholecystitis attack history, and accompanying chronic diseases are risk factors for conversion to open surgery. ${ }^{6-11}$ In our study, we determined that male gender and accompanying chronic diseases may be risk factors for conversion to open surgery but advanced age ( $>65$ years) and previous acute cholecystitis attack are not be risk factors. In patients operated on during acute cholecystitis attack, having increased bladder wall thickness and hydropic gallbladder, the conversion to open surgery increased statistically significantly $(\mathrm{p}<0.05)$.

Salman et al. have determined that BMI $>27$ might be a risk factor for conversion to open surgery. They have stated that this risk may be caused by increased intraperitoneal fatty tissue. They believe that this increase in fatty tissue may make it difficult to control hemorrhage during the dissection. ${ }^{11}$ But we determined that in the normal BMI group (20-25) frequency of conversion to open surgery was statistically significant $(\mathrm{p}<0.05)$. High BMI was not found to be a risk factor for conversion to open surgery.

For patients with abdominal surgery history, the problem during LC is intraabdominal adhesions. Although intraabdominal adhesions generally depend on a surgical intervention and they are also seen in cases of peritonitis, endometriosis, pelvic inflammatory disease, long-lasting peritoneal dialysis, radiotherapy, and cancer. ${ }^{12}$ In many studies, it has been stated that abdominal and epigastrium surgery might be a risk factor for conversion to open surgery. ${ }^{13,14}$ However, there also are publications stating that it is not a risk factor. ${ }^{15,16}$ In our study, we determined that prior abdominal surgery was not a risk factor but an adhesion makes dissection in Calot's triangle more difficult and this is a risk factor for conversion to open surgery $(\mathrm{p}<0.05)$.

For patients having pancreatitis attack during the laparoscopic operation or obstruction in the biliary tract, operation after ERCP is recommended. ${ }^{17}$ The ERCP has been reported to be a risk factor for conversion to open surgery due to the adhesions that may develop after sphincterotomy. ${ }^{11}$ In our study, we determined that ERCP performed before the operation is a risk factor $(\mathrm{p}<0.05)$. 
Many authors have reported that preoperative increased WBC, FBG, AST, ALT, ALP, and GGT levels might be a risk factor for conversion to open surgery. ${ }^{18,19}$ In our study, we determined that high FBG and WBC levels are the risk factors but high AST, ALT, ALP, and GGT levels are not.

Consequently, in our study, male gender, chronic disease history, normal (20-25) BMI level, increased gallbladder wall thickness, high preoperative blood glucose level and leukocytosis, ERCP history, grade 3 or 4 adhesions found during the operation, and the presence of multiple stones in the bladder were found to be statistically significant risk factors for conversion to open surgery $(\mathrm{p}<0.05)$. Knowing these risk factors is important for planning the treatment phases and informing patients before the operation.

\section{References}

1. Yıldız B, Abbasoğlu O, Hamaloğlu E, Ozdemir A, Sayek I. Determinants of postoperative infection after laparoscopic cholecystectomy. Hepatogastroenterology. 2009;56(91-92):589-592.

2. Ballal M, David G, Willmott S, Corless DJ, Deakin M, Slavin JP. Conversion after laparoscopic cholecystectomy in England. Surg EndosC. 2009;23(10):2338-2344.

3. Blauer KL, Collins RL. The effect of intraperitoneal progesterone on postoperative adhesion formation in rabbits. Fertil Steril. 1988; 49(1):144-149.

4. Ersöz F, Arıkan S, Bektaş H, Özcan Ö, Sarı S. The role of laparoscopic subtotal cholecystectomy in difficult laparoscopic cholecystectomy operations. Ulus Cerrahi Derg. 2009;25:105-108.

5. Wiseman JT, Sharuk MN, Singla A, et al. Surgical management of acute cholecystitis at a tertiary care center in the modern era. Arch Surg. 2010;145(5):439-444.

6. Genc V, Sulaimanov M, Cipe G, et al. What necessitates the conversion to open cholecystectomy? A retrospective analysis of 5164 consecutive laparoscopic operations. Clinics (Sao Paulo). 2011;66(3): $417-420$.
7. Abbasoğlu O. Safra kesesi Hastalıkları. In: Temel Cerrahi. Sayek I, Güneş Kitabevi, eds. $4^{\text {th }}$ ed. Ankara 2013, 1627-1637.

8. Lo CM, Fan ST, Liu CL, Lai EC, Wong J. Early decision for conversion of laparoscopic to open cholecystectomy for treatment of acute cholecystitis. Am J Surg. 1997;173(6):513-517.

9. Schafer M, Krahenbuhl L, Buchler MW. Predictive factors for the type of surgery in acute cholecystitis. Am J Surg. 2001;182(3):291-297.

10. Sanabria JR, Gallinger S, Croxford R, Strazberg SM. Risk factors in elective laparoscopic cholecystectomy for conversion to open cholecystectomy. J Am Coll Surg. 1994;179(6):696-704.

11. Salman B, Akın M, Tezcaner T, et al. Laparaskopik kolesistektomiden açık kolesistektomiye dönülen hastalarda preoperatif risk faktörleri ve intraoperatif nedenler: 536 retrospektif analizi. Gazi Medical Journal. 2008;19:60-65.

12. Cheong YC. Peritoneal healing and adhesion formation/reformation. Hum Reprod Update. 2001;7(6):556-566.

13. Ercan M, Bostancı EB, Teke Z, et al. Predictive factors for conversion to open surgery in patients undergoing elective laparoscopic cholecystectomy. J Laparoendosc Adv Surg Tech A. 2010;20(5):427-434.

14. Lee NW, Collins J, Britt R, Britt LD. Evaluation of preoperative risk factors for converting laparoscopic to open cholecystectomy. Am Surg. 2012;78(8):831-833.

15. Hutchinson CH, Traverso LW, Lee FT. Laparoscopic cholecystectomy. Do preoperative factors predict the need to convert to open? Surg Endosc. 1994;8(8):875-888.

16. Özkan E, Yıldız MK, Çakır T, et al. Outcome analysis of laparoscopic cholecystectomy in patients 65 years and older. Ulus Cerrahi Derg. 2012;28:88-91

17. Nair RG, Dunn DC, Fowler S, Mc Cloy RF. Progress with cholecystectomy: Improving results in England and Wales. Br JSurg. 1997;84(10): 1396-1398.

18. Oymaci E, Ucar AD, Aydogan S, Sari E, Erkan N, Yildirim M. Evaluation of affecting factors for conversion to open cholecystectomy in acute cholecystitis. Prz Gastroenterol. 2014;9(6):336-341.

19. Licciardello A, Arena M, Nicosia A, et al. Preoperative risk factors for conversion from laparoscopic to open cholecystectomy. Eur Rev Med Pharmacol Sci. 2014;18(2 Suppl):60-66. 